\title{
五十肩に対する磁気治療器の検討
}

1）関西銊尒短期大学 東洋医学教室

2) 近畿大学 薬理学教室

3）ピップフジモト株式会社 開発研究部

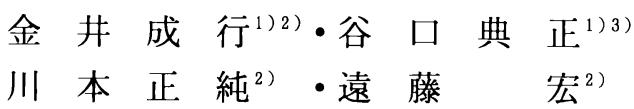

\section{Therapeutic Effects of Magnetic Fields on Frozen Shoulder}

\section{Shigeyuki Kanai ${ }^{122)}$, Norimasa Taniguchi ${ }^{13)}$, Masazumi Kawamoto ${ }^{2)}$, and Hiroshi Endo ${ }^{2)}$}

1) Department of Anatomy, Kansai college of Acupuncture Medicine

2) Department of Pharmacology Medicine Kinki University School of Medicine

3) Department of Science PIP-FUJIMOTO Co. Ltd

\begin{abstract}
A pathohysiological study of frozen shoulders was carried out by assessing thermography and deep body thermometry results together with the patients' subjective and objective symptoms. Active and dummy magnets were randomly assigned to patients (18 males and 20 females) in a double-blind study. All patients were magnets for three weeks, and subjective and objective symptoms were observed to be improved significantly 1 week after the application of the active magnets. The skin and deep body temperatures in the painful portion significantly increased with exposure to the active magnets at 2 weeks and 3 weeks after the application.
\end{abstract}

These findings suggest that the static magnetic fields might gradually increase blood circulation.

Key words : Static magnetic fields (静磁場), frozen shoulder (五十肩), thermography (サーモグ ラフィー)

はじめに

最近, 静磁気の作用により血管運動を活性化するこ と ${ }^{2-3)}$ や血流促進の効果があること故が報告されてい

る. また，虚血性の疼痛に対して鎮痛効果を示すこ と1も確認されている，今回我々は，肩関節痛を訴え る患者いわゆる “五十肩”に磁気治療器を貼付して興 味深い結果を得たので報告する.

\section{対象及び方法}

平成 11 年 3 月より当大学研究施設において肩関節 痛及び運動制限を訴え, いわゆる “五十肩”之思われ た 38 名（男 18 名, 女 20 名・平均 57 歳）の患者を対 象とした. 患者の割付は置換ブロック法により乱数表
を用いて無作為に行い, 磁気治療器群 18 名, ダミ一 治療器群 20 名に分けた。臨床試験は二重盲検法にて 行った.

測定方法は磁気治療器及びダミー治療器を装着した 患者に対して, 装着直前, 装着 $1 \mathrm{~W}$ 後, $2 \mathrm{~W}$ 後, $3 \mathrm{~W}$ 後及び脱着 $1 \mathrm{~W}$ 後の自他覚症状を検討するとともに, 客観的指標として肩関節表面温度及び深部温度の測定 を行った．磁気治療器とは，表面磁束密度 $160 \pm 10 \mathrm{~m}$ $\mathrm{T}, \quad \phi 15 \mathrm{~mm}$, 厚さ $7.2 \mathrm{~mm}$ の碁石状磁石を肩関節サ ポータ全面に貼付したものを使用した。 また，対照群 となるダミ一治療器群には, 表面磁束密度 $10 \mathrm{mT}$, 同 型，同サイズの物を同様に使用した。

尚, 測定に当たっては, 室温 $25^{\circ} \mathrm{C}$, 湿度 70〜 75\% 無風の恒温・恒湿室で, 患者には環境順応のため入室 
表1 自・他覚症状の評価

\begin{tabular}{|c|c|c|c|}
\hline \multicolumn{2}{|c|}{ 項目点数評価ランク } & 点数 & 評 価 \\
\hline 発 & 痛 & 3 & 症状なし：0点 \\
\hline 間 & 痛 & 3 & 軽 度: 1 点 \\
\hline 圧 & 痛 & 3 & 中程度: 2 点 \\
\hline 運＼cjkstart動 制 & 限（外転, 外施） & 3 & 重 度: 3 点 \\
\hline \multirow{2}{*}{$\begin{array}{l}\text { 患者による } \\
\text { 全般的疼痛 } \\
\text { 評価(VAS) }\end{array}$} & 昼間の痛み & 10 & \\
\hline & 夜間の痛み & 10 & \\
\hline 合 & 計 & 32 & \\
\hline
\end{tabular}

改善度 $(\%)=\frac{\text { 治療前の合計点数 }- \text { 治療後合計点数 }}{\text { 治療前合計点数 }} \times 100$

自覚症状は Visual Analogue Scale (VAS)

他覚症状は医師評価項目に従い点数化

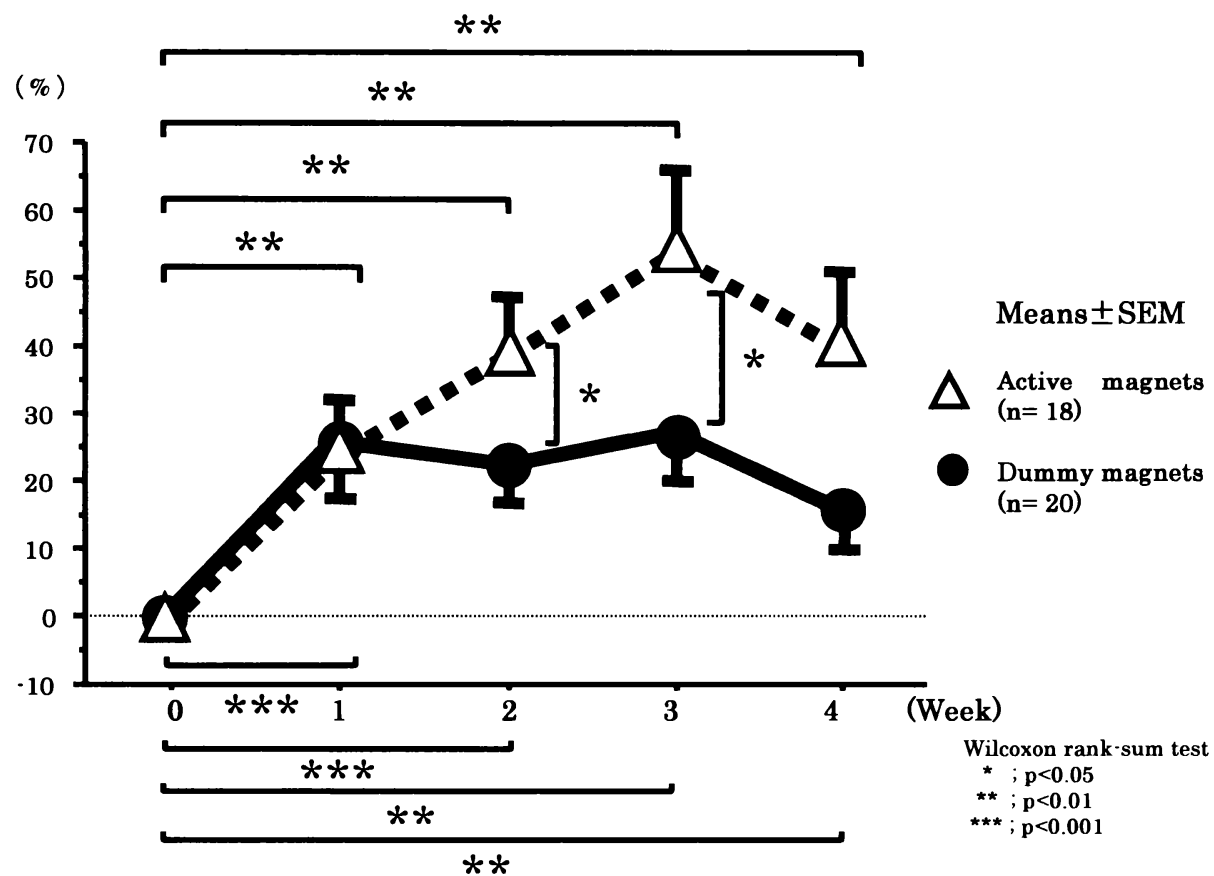

図 1 自・他覚症状の推移

改善度は, 貼付 1 週目より, 有意に改善した

後 15 分間安静後測定を行った.

自他覚症状の評価は，表 1 の如く6つの項目に分け, それぞれ, 症状に応じて点数化し, 治療前後で, 改善 度として検討を行った。

結果

1）自・他覚症状の推移
磁気治療群においては, 装着 1 週間後から改善が認 められ, その効果は, 装着終了後の 3 週間後で最大と なり, ダミ一群と比べて有意な差が認められた．また, 治療器を除去した 1 週間後でも治療効果が持続してい ることが確認された（図1）.

2 ) 肩関節表面温度の推移

治療群の肩表面部の平均温度は, 装着 1 週間後より 


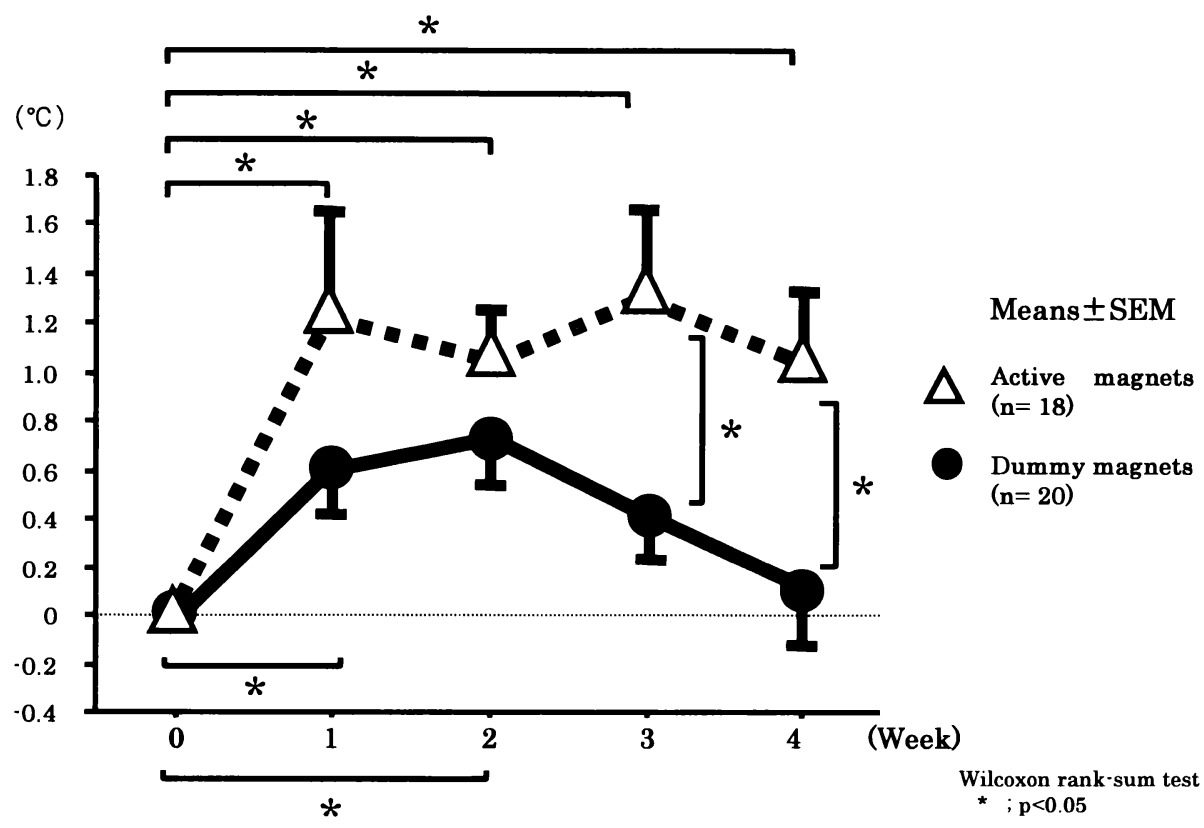

図 2 肩関節表面温度差の推移

治療群では装着 1 週間後にて有意な上昇が認められた

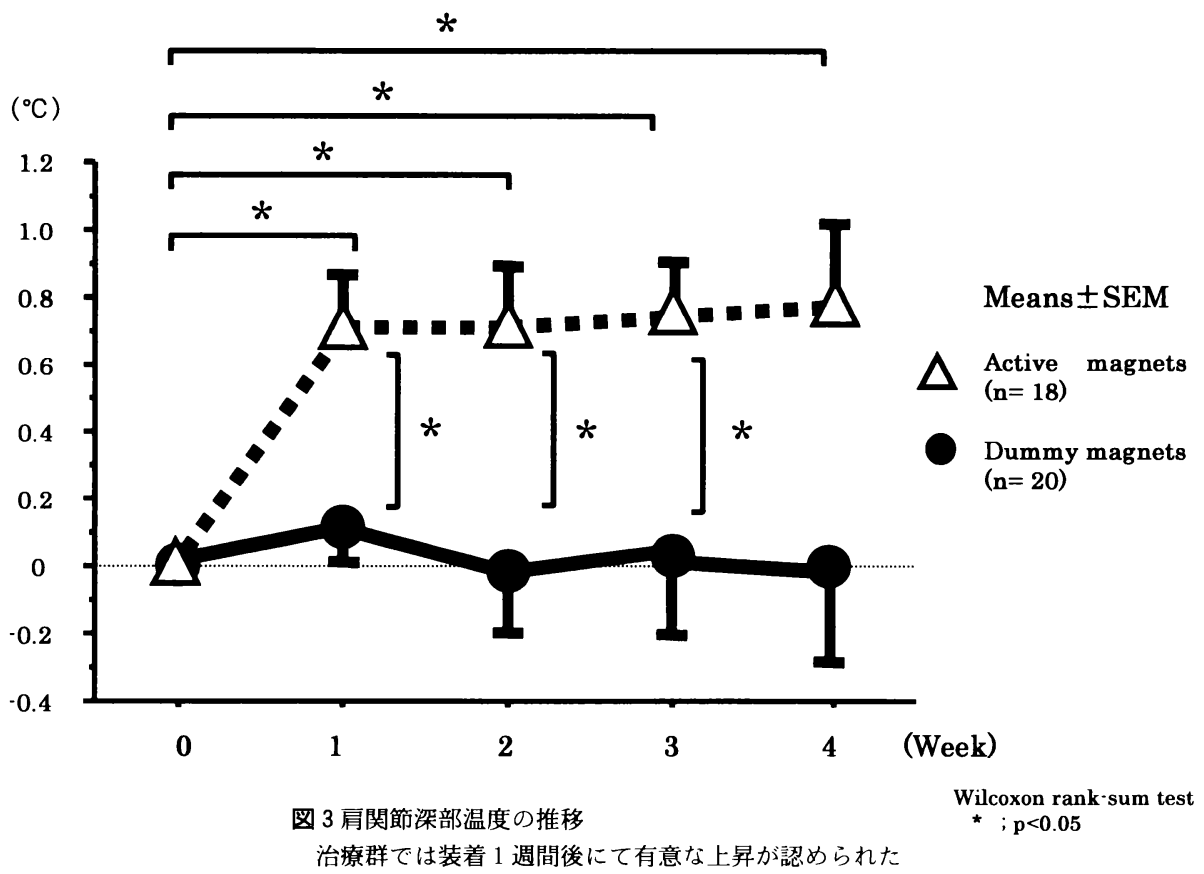


上昇し，装着終了の 3 週間後であ有意に上昇が認めら れ，自・他覚症状の改善とともにパラレルに推移した. 治療群, ダミ一群での上昇温度差を比較すると, 治療 群では装着 3 週間後にてダミー群に比べて有意な上昇 が認められた（図 2 ).

3 ) 肩関節深部温度の推移

治療群の深部温度は装着 1 週間後より上昇し, 除去 1 週間経過してもその効果は持続した. 治療群, ダミー 群での上昇温度差を比較すると, 治療群では装着 1 週 間後にてダミー群に比べて有意な上昇が認められた (図 3 ).

\section{考察}

肩関節拘縮と運動性疼痛を主訴とする疾患の中で原 因が不明であるあのを“五十肩”として扱い，日常診 療では暧昧な定義のもとに使用されている ${ }^{4}$. 今回, 我々も五十代前後の初老期で肩関節の拘縮と疼痛を訴 える原因疾患が明らかなものを除外した患者に磁気治 療器の効果を試みた。磁気には, 血流改善作用が報告 されており，その作用メカニズムとしては磁気によっ てコリンエステラーゼの活性が抑制され，コリン作動 性神経の末端から遊離されるアセチルコリンの量を増 大させることによって，血管を拡張させるものと考え られている5 ${ }^{5}$. 従って本研究で得られた皮㲊温度及び 深部温度の上昇もこのようなメカニズムによることが 推察される。これらのことから五十肩に関して今回認 められた磁気治療器の効果は, 静磁気の血流改善効果 により疼痛物質や炎症性メディエーターが排除された 可能性があると考えられる．ただ，疼痛及び拘縮の程 度等症例の選択にまだまだ考慮の余地があり更なる研
究・検討が必要であると考えられる.

$$
\text { 結語 }
$$

1. “五十肩”患者に磁気治療器を装着すると, 自・ 他覚症状の改善は 1 週間目より認められその効果 は除去するまで持続した。

2. 肩関節の皮虞表面温度及び深部温度も症状の改善 とともに上昇が認められた。

3. 磁気により血液循環が改善され, 肩関節の慢性炎 症が軽減された可能性のあることが示唆された。

\section{参 考 文 献}

1) Kanai S. et al : Therapeutic Effects of Static Magnetic Fields on Various Painful Conditions. International Symposium on New MAGNETO-SCIENCE' 99 : 412-422. 1999

2) Ohkubo C, Xu S : Acute Effects of Static Magnetic Fields on Cutaneous Microcirculation in Rabbits, International Journal of In Vivo Researchll : 221 - 226. 1997

3) Okano H, Gmitrov J and Ohkubo C: Biphasic Effects of Static Magnetic Fields on Cutaneous Microcirculation in Rabbits, Bioelectromagnetics 20:161171. 1999

4）营本一臣他 : 五十肩の病態 : 整形・災害外科 $43: 5-7$. 2000

5) Takeshige, C. : Comparison of pain relief mechanism between needling to the muscle, static magnetic field, external qugong and needling to the acupuncture point, Acupunct Electrother Res. 21, 119-131, 1996

6) Xu S, Okano $\mathrm{H}$ and Ohkubo C: Subchronic Effects of Static Magnetic Fields on Cutaneous Microcirculation in Rabbits, International Journal of In Vivo Research $12: 383-390.1998$ 